\title{
Biomolecular relationship of whole protein of Mannheimia haemolytica, Pasteurella trehalosi and Pasteurella multocida of sheep
}

\author{
Amal M. El-Sawah ${ }^{1 *}$, Eman M. El-Rawy ${ }^{2}$ \\ ${ }^{I}$ Central Laboratory for Evaluation of Veterinary Biologics, Abbasia, Cairo and ${ }^{2}$ Veterinary Serum \\ and Vaccine Research Institute, Abbasia, Cairo
}

\begin{abstract}
$P$. multocida contains one or more antigenic determinant of different proportions responsible for partial protection offered by the heterologous serovars. SDS-PAGE analysis of the whole protein profile prepared from sheep local isolates of $P$. multocida types (A, D), Mannheimia haemolytica type (A), P. trehalosi type (T) as well as standard strain of $P$. multocida (B6) revealed that the protein profile exhibited some differences with variable molecular masses ranged between 14 to $116 \mathrm{kDa}$. There are sharing protein subunits of molecular masses of 66,37 and $28 \mathrm{kDa}$ as the unique cross-reactive antigens in all isolates. The protection percentage for the vaccinated mice with inactivated $M$. haemolytica against the challenge with virulent strain of $P$. multocida type A, D and $\mathrm{B} 6$ are $30 \%, 30 \%$ and $20 \%$ respectively and $25 \%, 25 \%$ and $20 \%$ respectively in the groups of mice vaccinated with inactivated $P$. trehalosi so, there is cross reaction but limited cross protection between pasteurella isolates. The suggested vaccine must contain local isolates of $P$. multocida serotypes A, D and B6 as well as M. haemolytica and $P$. trehalosi.
\end{abstract}

Pasteurellosis is one of the most important diseases of sheep and goats throughout the world (Zamri Saad et al., 1987). Both Pasteurella haemolytica and Pasteurella multocida have been incriminated with septicaemic and pneumonic pasteurellosis (Gilmour, 1980). Pasteurella multocida is a heterogenous bacterial pathogen infecting domestic and wild animals. The heterogenicity of this bacterium is most evident from the fact that distinct capsular serotypes (A, B, D, E and F) occur within the species (Rimler and Rhoades, 1989). Pasteurella haemolytica was more frequently incriminated with pneumonic pasteurellosis than P. multocida. The isolated $P$. multocida showed considerable serological heterogenicity between the isolates of the types D, A and B (Shigidi and Mustafa, 1980). The agglutinagens of $P$. multocida contain one or more antigenic determinants of different proportions responsible for cross reaction (Rebecca et al., 1995), there were partial cross protection afforded by the heterologous serovars. Alaa et al. (2004) stated that the antigenic extracts from a local isolate of $M$. haemolytica (A2) are effective potential candidates for serodiagnosis of wide serovars of $M$. haemolytica infection in livestock animals. A37 $\mathrm{kDa}$ antigenic determination was $M$. haemolytica (A2) specific immunoreactive protein subunit in its OMP extracts. The most

\footnotetext{
* Corresponding author. Tel.: +202 3422505;

Fax: +202 3449204

E-mail address: clevb@tedata.net.eg

(Amal M. El-Sawah)
}

unique cross-reacting antigens in OMP of $\mathrm{P}$. trehalosi (T4) and P. multocida (B6) versus polyclonal anti- $M$. haemolytica A2 antiserum were at $66,44,43,41 \mathrm{kDa}$ that could be potential pasteurella related surface antigens for stimulating cross protecting immunity. These antigens are probably important resistance related antigens that should be considered a construction of subunit and/or adjuvant vaccine. Apparently, resistance to pasteurellosis is mediated by multiple antigenic determinants and therefore a combination of more than one serotype-specific antigen is needed for complete protection.

The present study was conducted to demonstrate biomolecular and cross reactivity relationship of the whole protein of Mannheimia haemolytica, Pasteurella trehalosi and Pasteurella multocida isolated from sheep.

\section{Materials and methods}

Bacterial isolates and culture. Sheep local isolate of $M$. haemolytica serotype A, P. trehalosi serotype (T) and P. multocida serotypes (A and D) were grown in brain heart infusion (BHI) or RPM1 media as needed and incubated aerobically overnight at $37^{\circ} \mathrm{C}$. All bacterial isolates have been subjected to phenotypic, biomolecular and serological characterization.

Standard strain. A vaccinal strain of $P$. multocida serotype B6 was grown in similar culture conditions that used for growing of the local isolates. The patterns of these isolates were 
analyzed in SDS-PAGE for the whole membrane protein.

Sodium Dodecyl sulphate polyacrylamide gel eletrophoresis analysis (SDS-PAGE). It was used according to the method of (Johnson et al., 1991). Protein marker mixtures of different molecular weight of concentration of $1 \mathrm{mg} / \mathrm{ml}$ were used in polyacrylamide gel electrophoresis SDS. Its molecular weight ranging from 14-116 kDa Cat. No. P.S.101 (Gibco BRL).

Rabbits. Six Boscat rabbit weighing 2-3 kg were used for passage of $P$. multocida strains.

Mice. A total of 180 Swiss Albino mice weighing about $18-20 \mathrm{~g}$ were used for the cross protection test. They were obtained from Veterinary Serum and Vaccine Research Institute, Abbasia, Cairo, Egypt.

Bacterial Culture. Two local isolates of $P$. multocida serotypes (A and D) and one standard strain of $P$. multocida serotype $\mathrm{B} 6$ were inoculated $\mathrm{S} / \mathrm{C}$ in Boscat rabbit. Reisolation of these strains from dead rabbits was done using sheep blood agar medium.

Biochemical identification. The suspected colonies of all serotypes were confirmed morphologically, culturally and biochemically by using API 20E according to (Quinn et al., 2002).

Serotyping of the isolates. Pure colonies of $P$. multocida, M. haemolytica and $P$. trehalosi were serotyped by IHA using standard specific antisera according to (Davies et al., 1997).

Preparation of whole protein membrane (Bacterial lysate). The whole bacterial cells of $P$. multocida serotypes $\mathrm{A}, \mathrm{D}$ and $\mathrm{B} 6, M$. haemolytica type A and P. trehalosi type (T) were harvested from cultures grown overnight at $37^{\circ} \mathrm{C}$ onto $7 \%$ sheep blood agar. The harvested cultures were washed twice in sterile normal saline. The bacterial cell pellets were treated with lysis buffer producing cell lysate according to (Broden and Rimler, 1982). Equal volume of Pasteurella isolates and $2 \mathrm{x}$ sample buffer $(10 \%$ glycerol, 4\% SDS, $0.02 \%$ bromophenol blue + $10 \%$ B. mercapto, $0.125 \mathrm{M}$ Tris $\mathrm{HCl}, \mathrm{pH} 6.8$ ) were mixed and placed in boiling water bath for 5 minutes according to (Davies et al., 1997).

Electrophoresis. The bacterial antigens were separated by discontinuous SDS-PAGE to obtain electrophoretic profiles of $P$. multocida and $M$. haemolytica isolates as described by (Johnson et al., 1991).

Vaccination of mice. A total of 180 albino mice about $18-22 \mathrm{~g} /$ weight were divided into 3 groups (60 mice for each): The first group was vaccinated with inactivated oil adjuvant $M$. haemolytica type (A). The second group was vaccinated with $P$. trehalosi type (T). The third group was kept as a control non-vaccinated. The vaccinated mice were inoculated with $0.2 \mathrm{ml} \mathrm{S} / \mathrm{C}$ in 2 doses with an interval of 15 days. The vaccinated and control groups were challenged with $0.1 \mathrm{ml} \mathrm{S} / \mathrm{C}$ of virulent strains of $P$. multocida after 21 days post the booster vaccination.

Each vaccinated group was subdivided into 3 subgroups and challenged 21 days post the second dose with $0.1 \mathrm{ml} \mathrm{S} / \mathrm{C}$ of virulent inoculum of $\mathrm{P}$. multocida type $\mathrm{A}, \mathrm{D}$ and $\mathrm{B} 6$ separately according to Ose and Muenster, (1986). The control groups received the same dilution of each challenged strains. Readings were recorded for 7 days.

\section{Results and Discussion}

Mannheimia (Pasteurella) haemolytica and other pasteurella species ( $P$. trehalosi and $P$. multocida) are Gram -ve bacteria responsible for economically important respiratory tract infections of cattle and sheep known as pneumonic pasteurellosis (Davies et al., 2002). Although the overall pathogens of bovine and ovine pneumonic pasteurellosis are very similar (Gilmour and Gilmour, 1989). M. haemolytica consists of genetically distinct subpopulation that are differentially adapted to elicit disease in either cattle or sheep (Davies et al., 1997).

Local isolates of $M$. haemolytica serotype (A), P. trehalosi (T), P. multocida serotypes (A, D) and standard strain of P. multocida (B6) in the present study were characterized morphologically, culturally, biochemically, serologically and molecularly as in Tables $(1,2)$.

Electrophoresis of the whole protein extracts, prepared from local isolates and standard strain of $M$. haemolytica, pasteurella species were exhibited some differences in their electrophoretic patterns as in Fig. 1,2 and Table (3). The whole protein profile of local isolates of $P$. multocida type A and $\mathrm{D}$, standard strain of $P$. multocida type (B6) as well as M. haemolytica type A and P. trehalosi (namely 1, 2, 3, 4, 5, 6) showed protein subunits of variable molecular masses ranged between 14 and $116 \mathrm{kDa}$. These results agreed with (Punchalski et al., 2002) who found that the presence of about 11 to 20 protein subunits with molecular masses ranged between 16 and $109 \mathrm{kDa}$ in OMP (outer membrane protein) of all serotypes of M. haemolytica and P. trehalosi. The data in Fig. (1 and 2) revealed that there are sharing protein subunits of 
molecular masses of $66,37.6$ and $28.5 \mathrm{kDa}$ in all isolates of Pasteurellae. These findings are supported by (Alaa et al., 2004) who found a considerable similarity of approximately (69\%) between $M$. haemolytica and $P$. trehalosi. Comparatively OMP profile of $P$. multocida (B6) showed slight similarity with that of $M$. haemolytica and P. trehalosi confined to protein subunits at molecular masses of about 66, 44, 41 and $35 \mathrm{kDa}$. The data illustrated in (Table 2, Fig. $1,2)$ for the protein profile of local isolates of $P$. multocida type A, D and standard strain of serotype B6 revealed that all isolates of $P$. multocida have similar protein profile with little additional protein as $56,33 \mathrm{kDa}$ in $P$. multocida type $\mathrm{D}, 51,16 \mathrm{kDa}$ in $\mathrm{P}$. multocida type $\mathrm{A}$ and the unique protein extra antigens as $53,35,33$ $\mathrm{kDa}$ in $P$. multocida type B6. These findings were in agreement with (Eman et al., 1998) who stated that the electrophoretic pattern of the overall protein pattern of $P$. multocida strains of cattle origin were visually similar, but there were some substantial difference between individual strains. The most majority of protein bands were located between 13-99 kDa molecular weights range. The minor protein of low amount of apparent molecular masses $17,18,31,34 \mathrm{kDa}$ appeared to be shared by all $P$. multocida field strains as well as standard type B6 strain and the minor protein band ranging from $20-35 \mathrm{kDa}$. The whole protein extracted from local isolate of $M$. haemolytica type (A) and P. trehalosi type (T) exhibited similar profiles with limited variation. The prominent proteins are $66,37,28 \mathrm{kDa}$ and a faint protein at $87 \mathrm{kDa}$. M. haemolytica showed additional protein at molecular weight of 116 $\mathrm{kDa}$. $P$. trehalosi showed some protein variation in the protein bands of molecular weights 47,41 , $14 \mathrm{kDa}$ and these data agree with Puchalski et al., 2002) who stated that the sharing protein at $44 \mathrm{kDa}$ was responsible for cross protection of $P$. trehalosi (the intensity of reaction of antihaemolytic serotype A1 with heterologic serum was stronger compared to the haemologic reaction for protein obtained from the nontypical strain (N2) localized in 16-31, 32, 44, 45, 72 and $100 \mathrm{kDa}$. Bosch et al., (2002) stated that the correlation between electrophoretic pattern and serotypic properties of isolates were established but no single protein band could be identified as unique to all strains that caused haemorrhagic septicaemia. OMP (outer membrane protein) bands at $(27,34,36 \mathrm{kDa})$ were common to all isolates regardless to serotype. One of the major virulence protein in
OMP was haemoglobin binding protein which was considered as specific receptor for hemoglobin. The findings in Table (4) revealed that there was a weak cross protection for the group of mice vaccinated with inactivated $M$. haemolytica type (A) against the challenge with virulent strains of $P$. multocida, the protection percentage were $30 \%, 30 \%$ and $20 \%$ against $P$. multocida type $\mathrm{A}, \mathrm{D}$ and $\mathrm{B} 6$ respectively with the overall of protection percentage of $30 \%$. In case of group of mice vaccinated with inactivated $P$. trehalosi $(\mathrm{T})$ and challenged with the virulent strains of $P$. multocida serotypes A, $\mathrm{D}$ and B6, the protection percentage was $25 \%$ against the challenge with the virulent strains of P. multocida type (A, D) and $20 \%$ against the challenge with $P$. multocida type B6 with overall of protection. The control group of nonvaccinated mice showed a $100 \%, 86$, and $90 \%$ mortality due to inoculation with virulent strains of P. multocida type A, D and B6 respectively with an overall mortality of $95 \%$. These results agreed with those obtained by (Eman et al., 2001) who stated that there is a cross reaction but limited cross protection between the isolates of $P$. multocida, M. haemolytica and $P$. trehalosi. In conclusion, the evolutionary relationship among $M$. haemolytica and $P$. trehalosi isolates indicates that the ancestral host is the sheep and several distinct colonal lineages have crossed the species barrier into cattle heterologous serovars and the agglutinogens of $P$. multocida contain one or more antigenic determinant of different properties are responsible for cross reaction between $P$. multocida isolates.

\section{References}

Alaa, A. E.; Eman, M. E.; Manal S. M. and Abd ElSalam, Z. H. (2004): Molecular characterization of Mannheimia haemolytica extracts and utility in serodiagnosis of pasteurellosis in Egypt. J. Egypt. Vet. Med. Assoc., 64 (3): 321-343.

Bosch, M.; Garrido, M. E.; Perez DeRozas, A. M.; Badiola, I. and Barbe, J. (2002): Characterization of $P$. multocida hgba gene encoding haemoglobin binding protein. Infect. Immun., 70 (11): 5955-5964.

Brogden, K. A. and Rimler, R. B. (1982): Lysate of turkey-grown $P$. multocida and examination of vaccine preparations by electron microscopy. Am. J. Vet. Res., 43 (2): 304-309.

Davies, L. R.; Susan, C. and Thomas S. W. (2002): Mosaic structure and molecular evolution of the leukotoxin operan in Mannheimia (Pasteurella) haemolytica, Mannheimia glucosidal and Pasteurella trehalosi. J. Bacteriol., 184 (1): 266-277.

Davies, R. L.; Arkinsaw, S. and Selander, R. K. (1997): Evolutionary genetics of Pasteurella haemolytica isolates recovered from cattle and sheep. Infect. Immun., 65: 35833593. 
Table (1): Biochemical properties of ovine pasteurella according to Quinn et al., (2002).

\begin{tabular}{lccccc}
\hline \multirow{2}{*}{ Fermentable substrates } & \multicolumn{3}{c}{ P. multocida } & $\begin{array}{c}\text { M. haemolytica } \\
\text { (A) }\end{array}$ & $\begin{array}{c}\text { P. trehalosi } \\
\text { (T) }\end{array}$ \\
\cline { 2 - 4 } Haemolysis onto blood agar & Serotype D & Serotype A & Serotype B & - & + \\
Growth on MacConkey & - & - & - & + & + \\
Indole test & - & - & - & - & - \\
Vogus Proskaur & - & + & + & - & - \\
Urea hydrolysis & - & - & - & - & - \\
Citrate utilization & - & - & - & - & + \\
Catalase test & - & - & - & + & + \\
Oxidase test & + & + & + & & + \\
Sugar fermentation & + & + & + & - & - \\
Salicin & - & - & - & - & - \\
Inulin & - & - & - & - & - \\
Lactose & - & - & - & - & + \\
Mannose & - & - & - & & - \\
Sucrose & + & + & + & + & - \\
Trehalose & - & + & - & - & + \\
Arabinose & - & - & - & + & + \\
Xylose & - & + & - & + & - \\
\hline
\end{tabular}

Table (2): Serotyping of ovine pasteurellae.

\begin{tabular}{lccc}
\hline & \multicolumn{3}{c}{ Pasteurella species } \\
\cline { 2 - 3 } & \multicolumn{2}{c}{$\boldsymbol{P}$. haltocida } & \multicolumn{2}{c}{ Paemolytica } \\
\cline { 2 - 4 } Serotypes & A & M. haemolytica type A & P. trehalosi type T \\
& B 6 & & \\
\hline
\end{tabular}

Table (3): SDS-PAGE analysis of the major subunits of whole protein extracted from type D, A, B6, M. haemolytica type A and P. trehalosi.

\begin{tabular}{lll}
\hline \multirow{2}{*}{ Bacterial isolate } & \multicolumn{2}{c}{ Approximate subunit molecular masses in kilodalton kDa SDS-PAGE } \\
\cline { 2 - 3 } & Prominent & Faint \\
\hline P. multocida type $D$ & $66,56,37.6,35$ & $87,33,28.5,18.4$ \\
$P$. multocida type $A$ & $66,51,37.6,42,28.5,18.4$ & $116,87,16$ \\
$P$. multocida type $B 6$ & $66,42,37,35,28.5,18.4,14.6$ & $116,87,53,33$ \\
M. haemolytica type $A$ & $116,66,37.6,33,28.5,18.4$ & 87,31 \\
$P$. trehalosi & $66,47,41,37,28,25$ & $116,87,18,14$ \\
\hline
\end{tabular}

SDS-PAGE: Sodium Dodecyl Sulphate Polyacrylamide Gel Electrophoresis

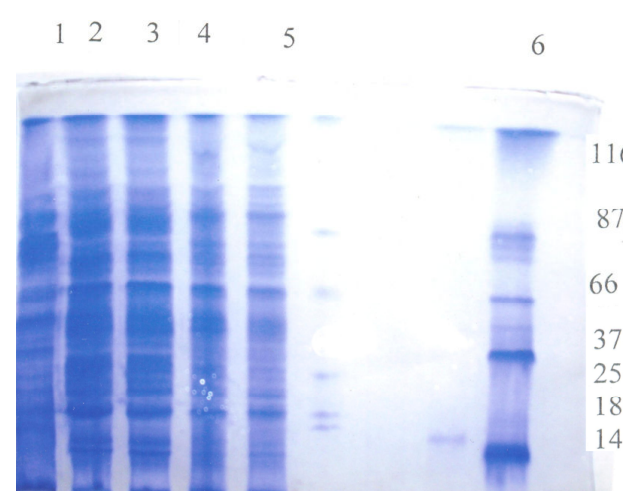

Fig (1)

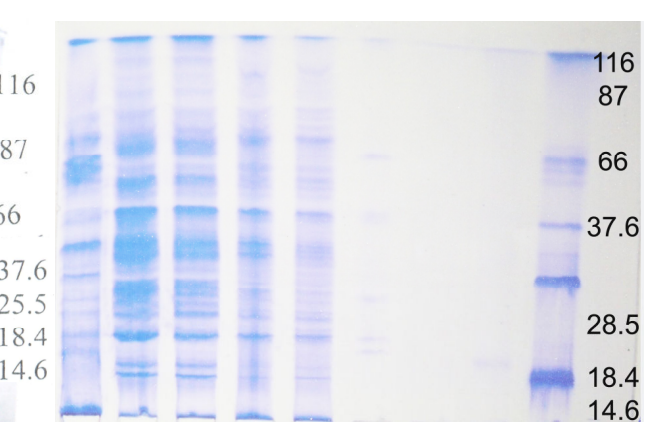

Fig. (2)

Fig. (1 and 2): SDS-PAGE analysis of whole protein extracts received from local isolates of ovine pasteurella separated through $2 \%$ denaturating polyacrylamide gel and stained with $0.1 \%$ bromophenol blue, $10 \%$ glycerol. Lane (1): P. multocida type (D), Lane (2): P. multocida type (A), Lane (3): P. multocida type (B), Lane (4): M. haemolytica type (A), Lane (5): P. trehalosi, Lane (6): Marker with molecular mass standard 14-116 kDa. 
Table (4): Determination of the cross protection for mice vaccinated with oil adjuvanted $M$. haemolytica and $P$. trehalosi against challenge with virulent strains of $P$. multocida.

\begin{tabular}{|c|c|c|c|c|c|c|c|c|c|}
\hline \multirow[b]{2}{*}{$\begin{array}{l}\text { Vaccinated } \\
\text { Groups }\end{array}$} & \multirow[b]{2}{*}{$\begin{array}{c}\text { No. } \\
\text { of } \\
\text { mice }\end{array}$} & \multicolumn{6}{|c|}{ Types of challenging serotypes } & \multirow[b]{2}{*}{$\begin{array}{c}\text { Total } \\
\text { No. of } \\
\text { survival }\end{array}$} & \multirow[b]{2}{*}{$\begin{array}{c}\text { Overall } \\
\text { protection } \\
\%\end{array}$} \\
\hline & & $\begin{array}{c}P . \\
\text { multocida } \\
\text { type A }\end{array}$ & P1 \% & $\begin{array}{c}P . \\
\text { multocida } \\
\text { type D }\end{array}$ & P2\% & $\begin{array}{c}P . \\
\text { multocida } \\
\text { type B6 }\end{array}$ & $\begin{array}{l}\text { P3 } \\
\%\end{array}$ & & \\
\hline & 60 & $6 / 20$ & $30 \%$ & $6 / 20$ & 30 & $4 / 20$ & $20 \%$ & $16 / 60$ & $30 \%$ \\
\hline & 60 & $5 / 20$ & $25 \%$ & $5 / 20$ & $25 \%$ & $4 / 20$ & $20 \%$ & $16 / 60$ & $23 \%$ \\
\hline $\begin{array}{l}\text { Control } \\
\text { Group }\end{array}$ & 60 & $0 / 20$ & $0 \%$ & $1 / 20$ & $2 \%$ & $2 / 20$ & $10 \%$ & $3 / 60$ & $5 \%$ \\
\hline
\end{tabular}

Group (1): Vaccinated with oil adjuvanted M. haemolytica in 2 doses of $0.2 \mathrm{ml} \mathrm{S} / \mathrm{C}$ Group (2): Vaccinated with oil adjuvanted $P$. trehalosi in 2 doses of $0.2 \mathrm{ml} \mathrm{S} / \mathrm{C}$

P1 \%: The No. of survived vaccinated against the challenge with virulent strain of P. multocida type A / total No. of vaccinated mice within the same group.

P2 \%: The No. of survived vaccinated mice against the challenge with virulent strain of P. multocida type D / total No. of vaccinated mice within the same group

P3 \%: The No. of survived vaccinated mice against the challenge with virulent strain of P. multocida type B6 / total No. of vaccinated mice within the same group

Eman M. E.; Susan F. G.; Gergism S. M. and Hussein, A. Z. (2001): Evaluation of the local prepared vaccine for protection against caprine pasteurellosis. J. Egypt. Vet. Med. Assoc., 61 (6C): 89-102.

Eman, S.A. Zaki; Abd Ekl-Ghani, M. and Gergis, S.M. (1998): Immunological studies on P. multocida in cattle. A Thesis of MD, Cairo Univ., Egypt.

Gilmour, N. J. L. (1980): Veterinary Annual (20): 234-235 Cited in Zamri M. S.; Sharif, H. and Basri, K. (1989): Microbiological and pathological evaluation of vaccination against naturally occurring caprine pasteurellosis. Vet. Rec., 124: 171-172.

Gilmour, N. J. L. and Gilmour, J. S. (1989): Pasteurellosis of sheep. P. 223-261. In C.F. Adlam and J.M. Rutter (ed). Pasteurella and Pasteurellosis. Academic Press, London, England.

Johnson, R. B.; Dawkins, H. J. S. and Spencer, T. L. (1991): Electrophoretic profiles of pasteurella isolates from animals with haemorrhagic septicaemia A. Am. Vet. Res., 52 (10): 1644-1648.

Ose, M. S. and Muenster, B. S. (1986): A method for evaluation of vaccines containing Pasteurella multocida. Am. J. Vet. Res., 29 (9): 1863-1866.
Puchalski, A.; Wernicki, A.; Mikucki, P. and UrbanChemiel, R. (2002): Profiles of outer membrane proteins from M. haemolytica, M. glucosida, P. trehalosi and nontypical strains. J. Bacteriol., 184 (1): 266-277.

Quinn, P. J.; Markey, B. K.; Carter, M. E.; Donnelly, N. J. C. and Leonard, F. C. (2002): Veterinary Microbiology and Microbial Disease. Ch. 22. Pasteurella species and Mannheimia haemolytica, pp. 137-143 Blackwell Science, MPG Books LTD, Bodmin, Carnwall, England.

Rebecca, J. M.; Paniciera, J.; Rober, W.; Fulton, Glynu, H. F.; Sidney A. E.; John T. H. and Anthony W. C. (1995): Vaccination of cattle with outer membrane protein enriched fraction of $P$. haemolytica and resistance against experimental challenge exposure. Am. J. Vet. Res., 56 (1): 875-879.

Rimiler, R. B. and Rhoades, K. R. (1989): In Pasteurella and Pasteurellosis, New York, Academic Press, pp. 37.

Shigidi, M. T. A. and Mustafa, A. A. (1980): Serological relationship between strains of P. multocida. Cornell Vet., 70: 27-36.

Zamri, S. M.; Sheikh Omar, A. R.; Chaoi, K. F. and Chulan, U. (1987): Isolation of $P$. haemolytica from the nasal cavity of goats perianika, 10: 246-247.

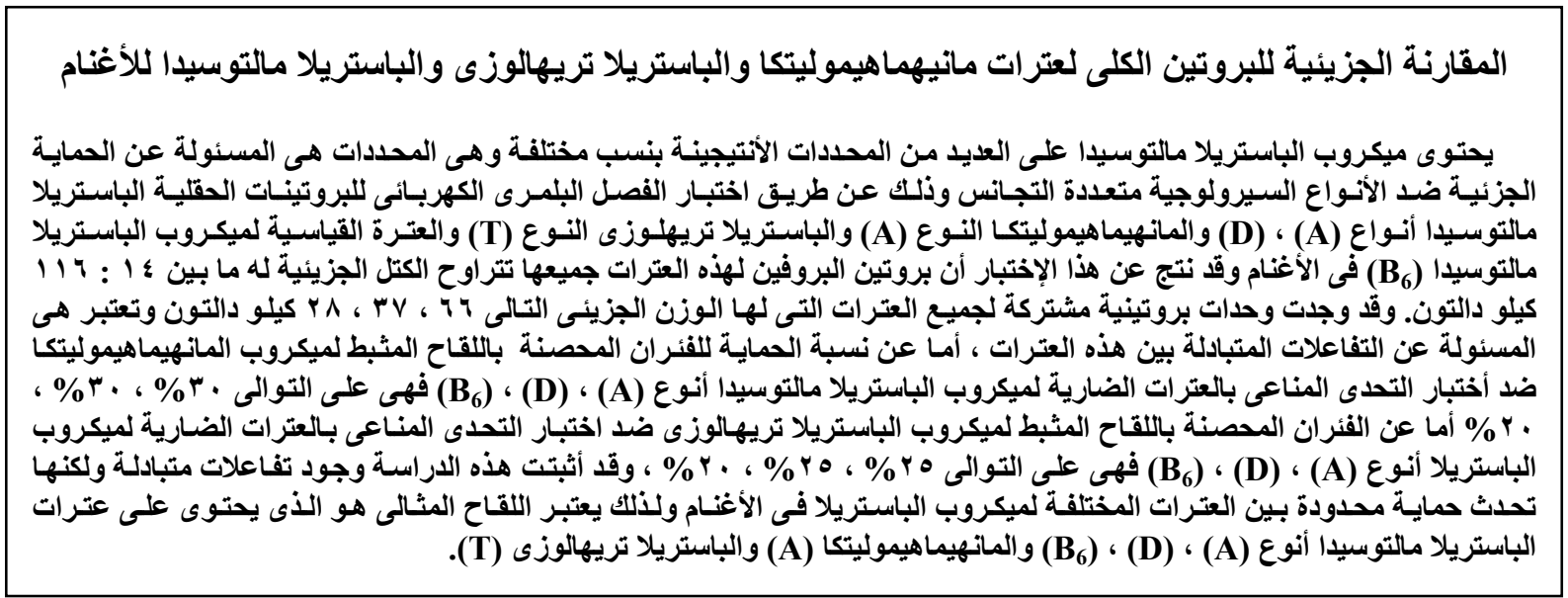

